\title{
Did Human Reality Denial Breach the Evolutionary Psychological Barrier of Mortality Salience? A Theory that Can Explain Unusual Features of the Origin and Fate of Our Species
}

\author{
Ajit Varki
}

"We now know that the human animal is characterized by two
great fears that other animals are protected from: the fear of
life and the fear of death." —Ernest Becker

"A being who knows that he will die arose from ancestors who did not know."

—Theodosius Dobzhansky

"The human race is the only one that knows it must die, and it knows this only through its experience."

- Voltaire

The yaksha asked: "What is the greatest surprise?" Yudhisthira replied: "People die every day, making us aware that men are mortal. Yet we live, work, play, plan, etc., as if assuming we are immortal. What is more surprising than that?"

- The Mahabharata

\begin{abstract}
Some aspects of human cognition and behavior appear unusual or exaggerated relative to those of other intelligent, warm-blooded, long-lived social species-including certain mammals (cetaceans, elephants, and great apes) and birds (corvids and passerines). One collection of such related features is our remarkable ability for ignoring or denying reality in the face of clear facts, a high capacity for self-deception and false beliefs, overarching optimism bias, and irrational risktaking behavior (herein collectively called "reality denial"). Such traits should be maladaptive for reproductive success when they first appear as consistent features in
\end{abstract}

\footnotetext{
A. Varki $(\triangle)$

Center for Academic Research and Training in Anthropogeny, University of California,

San Diego, CA, USA

e-mail: a1varki@ucsd.edu
} 
individuals of any species. Meanwhile, available data suggest that self-awareness (knowledge of one's own personhood) and basic theory of mind (ToM, also termed mind-reading, intentionality etc.) have evolved independently several times, particularly in the same kinds of species mentioned above. Despite a long-standing opportunity spanning tens of millions of years, only humans appear to have gone on to evolve an extended ToM (multilevel intentionality), a trait required for optimal expression of many other unusual cognitive attributes of our species, such as advanced linguistic communication and cumulative cooperative culture. The conventional view is that extended ToM emerged gradually in human ancestors, via stepwise positive selection of multiple traits that were each beneficial. A counterintuitive alternate possibility is that establishment of extended ToM has been repeatedly obstructed in all other species with the potential to achieve it, due to a "psychological evolutionary barrier," that would arise in isolated individuals of a given species that develop the genetic ability for extended ToM. Such individuals would observe deaths of conspecifics whose minds they fully understood, become aware of mortality, and translate that knowledge into mortality salience (understanding of personal mortality). The resulting conscious realization and exaggeration of an already existing intrinsic fear of death risk would have then reduced the reproductive fitness of such isolated individuals (by favoring personal survival over reproduction). This "psychological evolutionary barrier" would have thus persisted until hominin ancestors broke through, via a rare and unlikely combination of cognitive changes, in which two intrinsically maladaptive traits (reality denial and extended ToM) evolved in the minds of the same individuals, allowing a "mind over reality transition" (MORT) over the proposed barrier. Once some individuals broke through in this manner, conventional natural selection could take over, with further evolution of beneficial aspects of the initial changes. This theory also provides a unifying evolutionary explanation for other unusual features of humans, including our recent emergence as the dominant species on the planet, and replacement of all other closely related evolutionary cousins, with limited interbreeding and no remaining hybrid species. While not directly falsifiable by experiment, the MORT theory fits with numerous facts about humans and human origins, and no known fact appears to strongly militate against it. It is also consistent with most other currently viable theories on related subjects, including terror management theory. Importantly, it has major implications for the human condition, as well as for many serious current issues, ranging all the way from lack of personal health responsibility to ignoring anthropogenic global climate disruption, which now threatens the very existence of our species.

An Unusual Theory from an Unlikely Source. An expert reader might choose to skip this chapter in the volume Evolutionary Perspectives on Death, as it is written by a physician-scientist without a track record of publications in evolutionary psychology. However, regarding mortality salience (awareness by an individual that his/her death is inevitable) the author has had much real-world experience. I was once an oncologist giving chemotherapy to patients in the early days when it rarely worked, and thus witnessed first hand the remarkable human ability to suppress the harsh reality of personal mortality as well as the unrealistic optimism of all parties 
involved. Many years of studying molecular differences between humans and our closest evolutionary relatives (including human-specific diseases) (Chou, Takematsu, Diaz, et al., 1998; Ghaderi, Springer, Ma, et al., 2011; Hayakawa et al., 2005; Hedlund, Padler-Karavani, Varki, \& Varki, 2008; Varki, 2000, 2010; Varki, Strobert, Dick, Benirschke, \& Varki, 2011; Wang, Mitra, Secundino, et al., 2012) and transdisciplinary interactions with scholars of many stripes interested in explaining human origins (Enard, Khaitovich, Klose, et al., 2002; Gagneux, Moore, \& Varki, 2005; Ghaderi et al., 2011; McConkey \& Varki, 2000, 2005; O'Bleness, Searles, Varki, Gagneux, \& Sikela, 2012; Olson \& Varki, 2003, 2004; Varki, 2007; Varki, Geschwind, \& Eichler, 2008) also prepared the author for a contrarian question posed to him in 2005 by the late Danny Brower of the University of Arizona: instead of asking what biological and cultural evolutionary processes generated the human mind, perhaps we should instead ask why we are not currently competing with other species with humanlike cognition. After all, warm-blooded, highly intelligent, socially complex species such as elephants, dolphins, whales, great apes, and corvids have been on this planet for tens of millions of years? So why are we not competing with other lineages with humanlike cognition, and have instead endangered them all by taking over the entire biosphere? Perhaps we should consider the possibility of a difficult cognitive barrier that only the lineage leading to humans was able to breach on a single occasion (Varki, 2009; Varki \& Brower, 2013).

Some Unexplained Distinctive Features of Humans and Our Evolutionary Origins. Each living species has unusual or distinctive features that emerge from evolutionary interactions between biology and environment. The symposium addressing Evolutionary Perspectives on Death exemplified two unusual features of humans: first, our ability to consider and understand the thoughts of many others at once (as occurred during the lectures and discussions); and second, our ability to dispassionately discuss knowledge of our own mortality without being consumed by fear. I will argue that these two seemingly disparate human peculiarities were involved in a critical interplay in relation to the origin of our species, also then contributing to our subsequent replacement and/or limited genetic assimilation of our closest (now extinct) evolutionary cousins - and eventually to our domination of the entire planet, two additional distinctive features of humans. I will first consider each of these human peculiarities individually, and then attempt to synthesize them into a single overarching theory, which can also explain many other aspects of the human condition and the origin of our species. Note that this is not one of the oftcriticized "umbrella theories" (Langdon, 1997) that seek to explain everything about human origins and cognition. Rather, it is a theory about a very finite period of human evolution, and the proposed breaching of a "psychological evolutionary barrier," which allowed our emergence as a cognitively distinct species. It is also a theory that appears to fit with all known relevant information, and is not apparently negated by any other facts, but also cannot be definitively falsified at this time by an experiment.

The Remarkable Human Propensity for "Reality Denial" in the Face of Facts or Realities. The human ability to understand and consider our own mortality without being consumed by fear seems natural to us. In fact, it appears to be just one 
manifestation of a peculiar human ability to ignore, rationalize, or outright deny obvious realities, and even to believe in multiple or alternate realities at the same time. For example, advances of in science and medicine have made it clear that health and longevity are improved if we exercise regularly, eat a balanced and healthy diet, avoid tobacco and excessive alcohol, maintain an optimal body weight, detect and treat high blood pressure or sleep apnea, avoid excessive stress, and so on-but very few of us follow these simple and logical recommendations (physicians are often among the worst offenders) (Freeman and Spiegelhalter 2018; Spiegelhalter, 2012). Even when we do acknowledge such realities, we tend to indulge in magical thinking, behaving as if these statistics apply to everyone else, but not to ourselves. Many humans also ignore or even deny scientific and societal realities such as biological evolution, anthropogenic climate change, human "overshoot" with nonrenewable resource depletion, gross degradation of our environment, massive expansion of national debt, ballooning healthcare costs, covert or overt racism, and so on. Instead, many continue to believe in UFOs, literal biblical creationism, magical cures, claims that vaccines do not work (or cause autism), irrational fear of all genetically modified organisms (GMOs), and so on. We also insist on rebuilding our dwellings in the places where the worst natural disasters have repeatedly occurred. On the political front, distortion or denial of obvious realities is prominent in all parties and belief systems, depending on the circumstances. Of course, scientists are also not immune to denying obvious realities, and phenomena like a heliocentric solar system (Copernicus), evolution (Darwin), plate tectonics (Wegener), blood circulation (Harvey), and antisepsis (Semmelweis) were strongly resisted at the time by learned colleagues in the face of facts, and some of these frustrated proponents did not even live long enough to be personally vindicated.

Absent a single entry in the dictionary to denote these and other related phenomena, I have taken the liberty of coining the term "reality denial" defining it as a subconscious defense mechanism characterized by refusal to acknowledge (or rationalization of) unwanted unpleasant facts, realities, thoughts, and feelings. There are many other ways to consider about this overall cognitive peculiarity, including "denialism" (Specter, 2009), "corruption of reality" (Schumaker, 1995), "cognitive dissonance" (Harmon-Jones, 2019), "predictable irrationality" (Ariely, 2008), "the believing brain" (Shermer, 2012), various views of "optimism bias" (Gilbert, 2007; Sharot, 2011a, 2011b; Sharot, Korn, \& Dolan, 2011; Sharot, Riccardi, Raio, \& Phelps, 2007; Weinstein, 1980), and so on. Whichever way we choose to define this broad phenotype, it is a common feature of humans, and (as far as we know) not common in other animals. Thus, it needs to be added to a list of our many unusually exaggerated cognitive characteristics (see Table 1 for a partial list). However, unlike most other features listed in Table 1 that should have had net benefits for positive adaptive selection during evolution when they first appeared, this capacity for persistent and sometimes extreme reality denial should have been a maladaptation when it first appeared in our lineage. Indeed, any individual who routinely practiced reality denial and took excessive risks would likely be removed from the gene pool of that species, and there would have been a failure to fix the genotype responsible for this phenotype. The questions then are the following: 
Table 1 Some unusual or exaggerated cognitive features of humans

\begin{tabular}{l|l|l}
\hline Acting (mime or spoken) & Caring for the sick & Planning ahead \\
\hline Bargaining & Hospitality & Reality denial $^{\mathbf{a}}$ \\
\hline Beliefs about death & Inheritance rules & Religiosity \\
\hline Blushing & Intentional deception & Representational art \\
\hline Bravery and courage & Language (complex) & Reputation (concern for) \\
\hline Care of infirm and elderly & Laws and justice & Risk-taking (excessive) \\
\hline Comedy & Lecturing & Rites of passage \\
\hline Control of fire & Medicines for others & Romantic infatuation \\
\hline Cooking & Magical thinking & Social control of paternity \\
\hline Cooperation & Multi-instrumental music & Suicide (intentional) \\
\hline Cumulative culture & Nonreciprocal altruism & Teaching (explicit) \\
\hline Domestication of Animals & Organized sports & Theory of mind (extended) $* \mathbf{a}$ \\
\hline Food preparation for others & Optimism bias & Torture (deliberate) \\
\hline Funerary practices & Overconfidence & Trade \\
\hline
\end{tabular}

aDeleting extended theory of mind and/or reality denial from the human cognitive repertoire would eliminate or diminish many of the other features in this table

How and why did excessive reality denial and risk-taking evolve in humans, and what benefits outweighed the obvious negative consequences, at the time when this propensity first emerged?

Extended Theory of Mind as Another Distinct Feature of Humans. Many warm-blooded species appear to have independently evolved self-awareness as defined by various criteria, including the mirror self-recognition test (Anderson \& Gallup, 2015; Candland, 1995; Gallup, 1977; Parker, Mitchell, \& Boccia, 1994; Ross et al., 2017; Suddendorf \& Butler, 2013), which has been passed by individual members of various species including chimpanzees (Anderson \& Gallup, 2015; Eddy, Gallup, \& Povinelli, 1996; Gallup, 1977; Kitchen, Denton, \& Brent, 1996; Povinelli, Eddy, Hobson, \& Tomasello, 1996; Rajala, Reininger, Lancaster, \& Populin, 2010), elephants (Dale \& Plotnik, 2017; Plotnik, de Waal, \& Reiss, 2006), dolphins (Morrison \& Reiss, 2018; Reiss, 2011; Reiss \& Marino, 2001), corvid birds (Clary \& Kelly, 2016; Prior, Schwarz, \& Güntürkün, 2008), and possibly even trained monkeys (Huttunen, Adams, \& Platt, 2017; Rajala et al., 2010; Toda \& Platt, 2015). The question arises whether such individuals with awareness of their own self are also fully aware of the self-awareness of others, a state that is often referred to as "theory of mind" (Apperly, 2010; Baron-Cohen, Leslie, \& Frith, 1985; Bedny, Pascual-Leone, \& Saxe, 2009; Crockford, Wittig, Mundry, \& Zuberbuhler, 2012; Dumontheil, Apperly, \& Blakemore, 2010; Emery \& Clayton, 2009; Gentner \& Goldin-Meadow, 2003; Kappeler \& Silk, 2010; Krupenye, Kano, Hirata, Call, \& Tomasello, 2016; Meltzoff, 1999; Moll \& Meltzoff, 2011; Moll \& Tomasello, 2012; Patel, Sestieri, \& Corbetta, 2019; Povinelli et al., 1996; Premack \& Woodruff, 1978; Schaafsma, Pfaff, Spunt, \& Adolphs, 2015; Young, Dodell-Feder, \& Saxe, 2010), or "intentionality" (Dennett, 1987, 1996; Tomasello, 2018) (i.e., the ability to not only attribute mental beliefs, desires, and perspectives to oneself, but also to understand that others have beliefs, desires, intentions, or perspectives similar or different from 
oneself). Many other terms describe aspects of such mental states, including "intersubjectivity" (Vogeley, 2017), "mind reading" (Apperly, 2010; Emery \& Clayton, 2009; Heyes \& Frith, 2014; Samson, 2009), "perspective taking" (Carter, 2002; Hodges, Denning, \& Lieber, 2018; Moll \& Meltzoff, 2011), and "other-regarding impulses" (Hrdy, 2009).

Of course such cognitive abilities are part of a continuum seen in the postnatal development of humans (Baron-Cohen et al., 1985; Baron-Cohen, O'Riordan, Stone, Jones, \& Plaisted, 1999; Bering \& Parker, 2006; Corriveau, Kim, Schwalen, \& Harris, 2009; Dumontheil et al., 2010; Hofmann, Doan, Sprung, et al., 2016; Luu, Rosnay, \& Harris, 2013; Meltzoff, 1999; Moll \& Meltzoff, 2011; Moll \& Tomasello, 2012; Parker et al., 1994; Piazza, Bering, \& Ingram, 2011; Povinelli et al., 1996; Ronfard, Bartz, Cheng, Chen, \& Harris, 2018; Ronfard, Chen, \& Harris, 2018; Wellman \& Brandone, 2009) (Fig. 1), with a 2-year-old recognizing herself in the mirror, the emergence of a rudimentary theory of mind or "collective intentionality" of a 3- or 4-year-old, and what one might call a full theory of mind or "multilevel intentionality" in a 5- or 6-year-old who can tell excellent lies (the ability to understand and deceive other minds). And in adult humans we have an "extended theory of mind," which can now encompass a billion minds across the Internet, simultaneously understanding the beliefs of others (whether or not they are true!).

Why Are We Humans Alone in Dominating the Planet? The continent of Africa was the source of a diverse and complex assemblage of hominin lineages that spread across the Old World beginning about two million years ago (Wood \& Boyle E, 2016), and evolved into multiple lineages of behaviorally sophisticated species, only a few which have been defined to date, such as Neanderthals, Denisovans, and "Hobbits" (Culotta, 2016; Hajdinjak, Fu, Hübner, et al., 2018; Meyer, Kircher, Gansauge, et al., 2012; Prufer, de Filippo, Grote, et al., 2017; Prufer, Racimo, Patterson, et al., 2014; Reich, Green, Kircher, et al., 2010). But once our own species emerged in Africa >200,000 years ago (Hublin, Ben-Ncer, Bailey, et al., 2017; Wood, 2017), and later spread across the planet (Clarkson, Jacobs, Marwick, et al., 2017; Galway-Witham \& Stringer, 2018), we quickly

Fig. 1 A continuum in the cognitive development of self-awareness, theory of mind (ToM), and intentionality
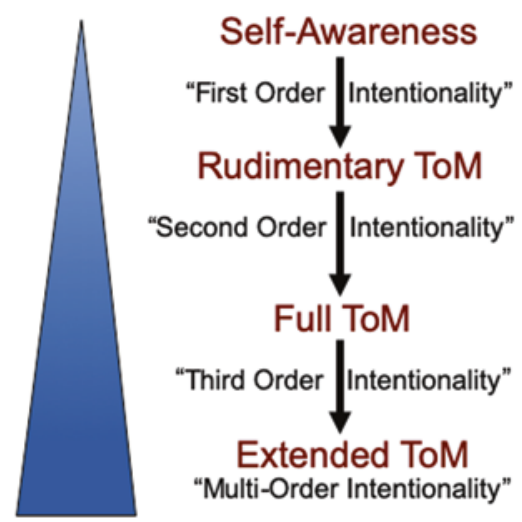

2-year-old Human

3-4-year-old Human

$\sim 5$-year-old Human

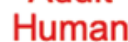


became (in evolutionary time) the "Lone Survivors" (Stringer, 2012) and "Masters of the Planet" (Tattersall, 2012). To a large extent, our success has been based on a constellation of unusual cognitive features, such as those listed in Table 1. However, if we "delete" our extended theory of mind, many of the other cognitive attributes become less effective (consider a group of individuals with autism spectrum disorder, who may each have special cognitive attributes, but are much less capable of cumulative, rapidly developing culture).

The cognitive benefits of extended theory of mind are many, and may have been necessary for the spread of humans all across the planet, and the development of our varied and complex cultures. Given the obvious benefits to fitness, the counterintuitive question posed to me by the late Danny Brower (Varki, 2009) was why are such abilities are so well developed in adult humans-yet apparently not in otherwise highly intelligent, large-brained, warm-blooded, social, tool-using species ranging from chimpanzees, elephants, dolphins, and other cetaceans, corvids, and the likelineages that have been on the planet for tens of millions of years of vertebrate evolution? Instead of the conventional assumption that something unusual happened in the course of human brain evolution, what if there was instead a difficult-tosurmount barrier that repeatedly blocked the cognitive progression of all other species? In other words, just as a physiological evolutionary barrier held back adaptation of vertebrate species from aquatic to terrestrial life for a very long time, what if there is a "psychological evolutionary barrier" (Fig. 2) that has repeatedly thwarted progression of cognitive evolution to the full state of multilevel intentionality?

When and How Did Humans Evolve Tolerance of Knowledge of Personal Mortality? It is reasonable to assume that most or all species with a nervous system have an automated reaction to death risk that has been honed by natural selection,

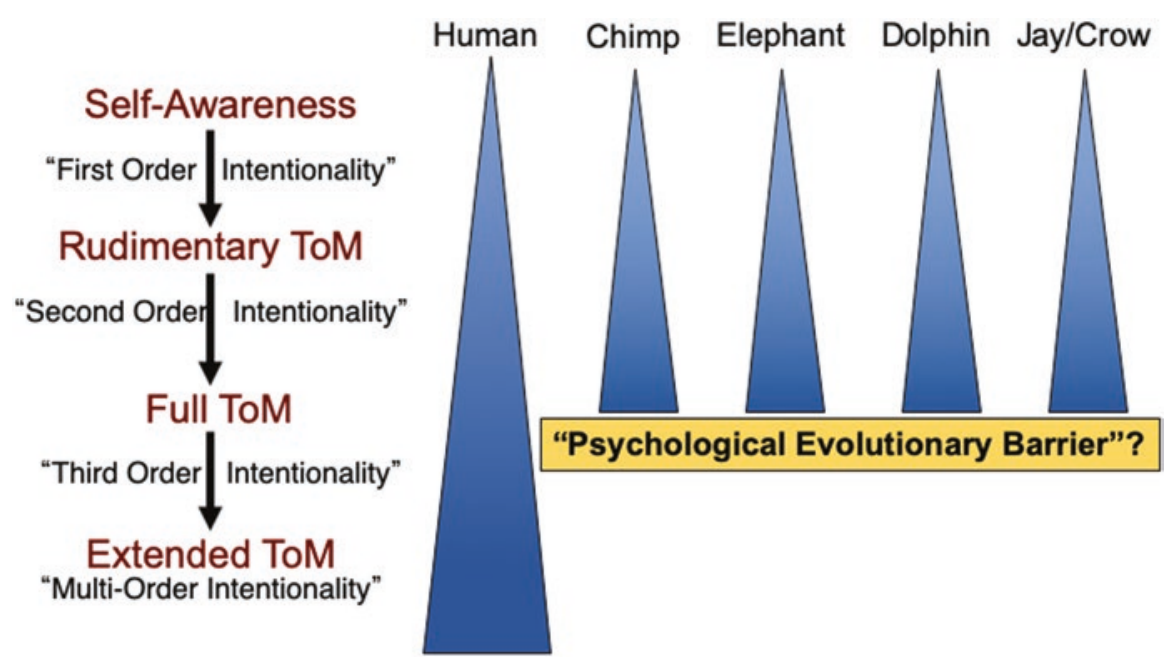

Fig. 2 A psychological evolutionary barrier to acquiring extended theory of mind 
and it is likely that all animals have genetically wired reaction responses to death risk. But only a small subset of animals (once again, including elephants, chimpanzees, cetaceans, and corvids) seem to show awareness of the death of a conspecific (Anderson, Gillies, \& Lock, 2010; Bearzi et al., 2018; Biro et al., 2010; Goncalves \& Biro, 2018; Goncalves \& Carvalho, 2019; Marzluff \& Angell, 2012; Porter, Eckardt, Vecellio, et al., 2019; Stewart, Piel, \& O’Malley, 2012), some descriptions of which can be found in another chapter of this volume (Brosnan \& Vonk). Of course, many behaviors and emotions we associate with humans are also present in other species to varying degrees (Safina, 2015, 2019; Waal, 2019).

Regardless, the question remains open as to whether members of such species also experience true mortality salience (i.e., a full understanding of the reality of their own personal mortality) as humans do-as opposed to simply recognizing the death of another individual they were close to and reacting negatively. It is reasonable to suppose that fully understanding the death and mortality of other individuals is a prerequisite to fully understanding one's own personal mortality. If so, the emergence of a full theory of mind would eventually result in full understanding of the death of another individual, i.e., the permanent extinction of another mind, not unlike oneself. This understanding should translate to stark realization of one's own personal mortality. Severe death anxiety should affect the few individuals who develop this ability at any given time, and this may have sufficiently reduce their fitness to negate the possibility of passing on the genotype to offspring (Fig. 3). Perhaps this is the psychological evolutionary barrier that has held back all other species to date.

Did Two Rare Evolutionary Maladaptations Coincide to Breach the Evolutionary Psychological Barrier of Mortality Salience? As discussed earlier, excessive reality denial and risk-taking should have been maladaptive each time that they first emerged in individuals of a species with advanced cognition. And we have just argued that although an extended theory of mind can have fitness value in the right circumstances (as it does in today's humans), the initial negative impact of the resulting mortality salience should be maladaptive, because of the resulting mortality salience and death anxiety. But if both of these very rare maladaptations happened

Fig. 3 A continuum in awareness of death risk and understanding of mortality. Potential consequences for evolutionary selection

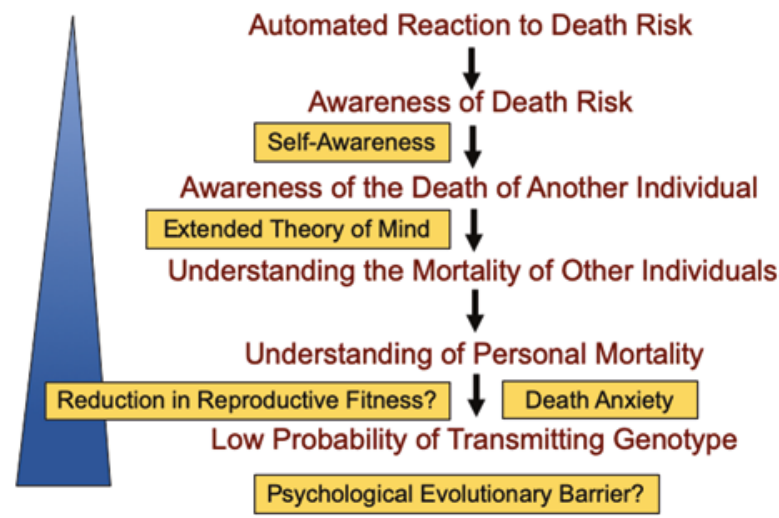


to evolve in the minds of the same individuals at the same time, they could combine to allow tolerance of death anxiety, and this unlikely combination could be genetically established in the progeny of these individuals (Fig. 4). In the more expanded view of this proposed "mind over reality transition" shown in Fig. 5, a species with a complex social organization, a long life, a preexisting maternal instinct, and helpless young could evolve (Froehle et al., 2019; Hrdy, 2009; Konner, 2010), such as occurs in some of the other mammals mentioned earlier. Such a species might also

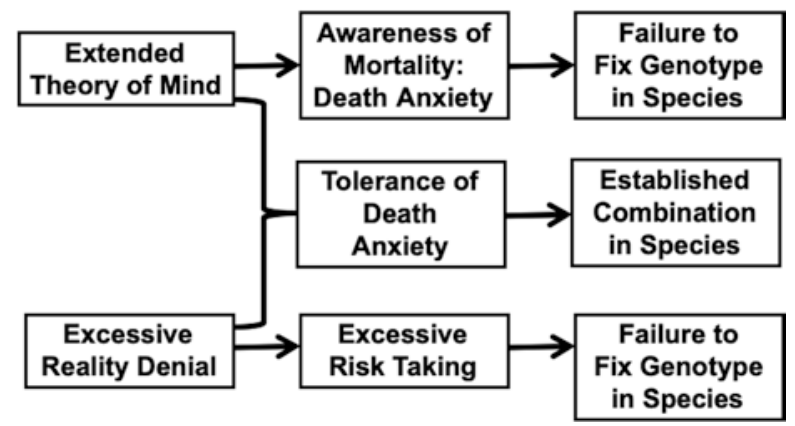

Fig. 4 "Mortality salience" barrier to establishment of an extended theory of mind in a species. A proposed mind over reality transition is based on unlikely coincidental combination of two maladaptive factors during human cognitive evolution

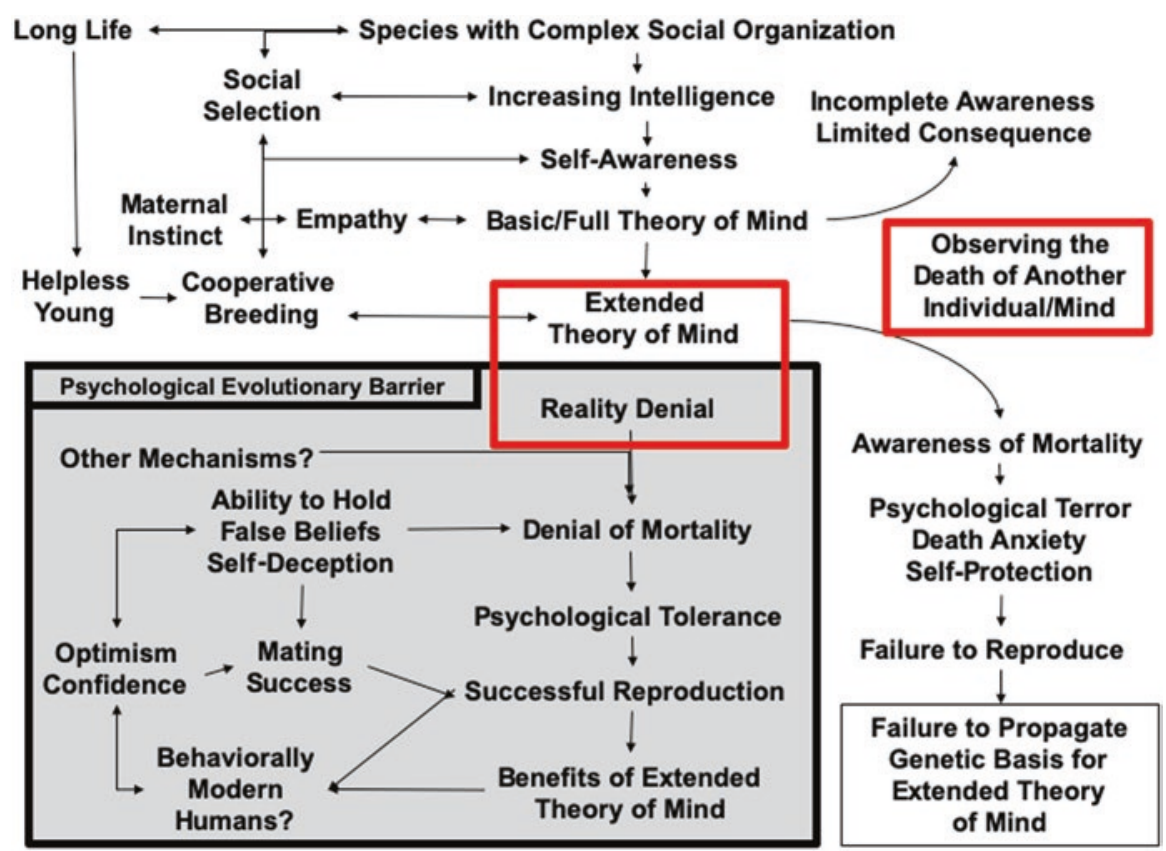

Fig. 5 Extended view of some factors involved in the proposed mind over reality transition 
be more likely to develop some level of self-awareness and basic theory of mind, especially in the context of cooperative caring for helpless young (Hrdy, 2009).

In the absence of a full theory of mind, observing the death of another individual of the same species would not trigger full mortality salience and its negative consequences (Fig. 5). On the other hand, individuals who first develop a full theory of mind and observe the death of conspecific would then suffer from awareness of personal mortality, and the resulting psychological terror would result in a failure to establish the genotype in that lineage. If so, a highly unlikely one-time combination that includes reality denial of mortality salience would allow psychological tolerance, successful reproduction, and establishment of the benefits of extended theory of mind (Fig. 5). It is also noteworthy that the ability to hold false beliefs, selfdeception, optimism, and confidence might support a successful mating strategy, especially for males. This suggestion is congruent with Trivers evolutionary theory of self-deception that includes denial of ongoing deception, self-inflation, egobiased social theory, false narratives of intention, and a conscious mind that operates via denial and projection to create a self-serving world (Murphy, von Hippel, Dubbs, et al., 2015; Ramachandran, 1996; Trivers, 2000, 2011).

One can thus posit a hypothetical singular phase in human evolution, during which mortality salience and maladaptive death anxiety were triggered by acquiring extended theory of mind, but happened to be stabilized by simultaneous evolution of reality denial in the same minds. Returning to Table 1, and doing the thought experiment, it is noteworthy that the combined deletion of reality denial and extended theory of mind would blunt or eliminate many of the unusual cognitive features of humans. Thus, once this unusual combination was established in the lineage that gave rise to modern humans, it would have given such individuals a considerable advantage at the cognitive level.

Can This Theory Help Explain the Unusual Origin of Our Species? Although new findings keep changing the numbers, it currently appears that modern humans evolved from a population of 5000-10,000 individuals in Africa $>2-300,000$ years ago (Nielsen et al., 2017; Scheinfeldt, Soi, Lambert, et al., 2019), and spread across the planet over the last 70,000-100,000 years or so (Clarkson et al., 2017; GalwayWitham \& Stringer, 2018), at about the time when the archeological record began to show symbolic art, complex toolmaking, personal ornamentation, and burials with grave goods - the kinds of features one might expect to see if a full theory of mind had emerged. It appears that these "behaviorally modern" humans then replaced all closely related species over a few thousand years, with limited interbreeding (Galway-Witham \& Stringer, 2018; Jacobs, Hudjashov, Saag, et al., 2019; Petr, Pääbo, Kelso, \& Vernot, 2019), leaving us as the only surviving hominin lineage, eventually gaining dominance over the entire biosphere. The fact that there are no persisting hybrids (Varki, 2016) suggests that a subset of anatomically modern humans may have gone through this "mind over reality transition" (Fig. 6), and then used extended theory of mind, reality denial, self-deception, false beliefs, an overarching optimism bias, and irrational risk-taking, to emerge as the dominant species. Of course, there is much evidence that Neanderthals shared many advanced cognitive features with humans (Finlayson, Brown, Blasco, et al., 2012; 


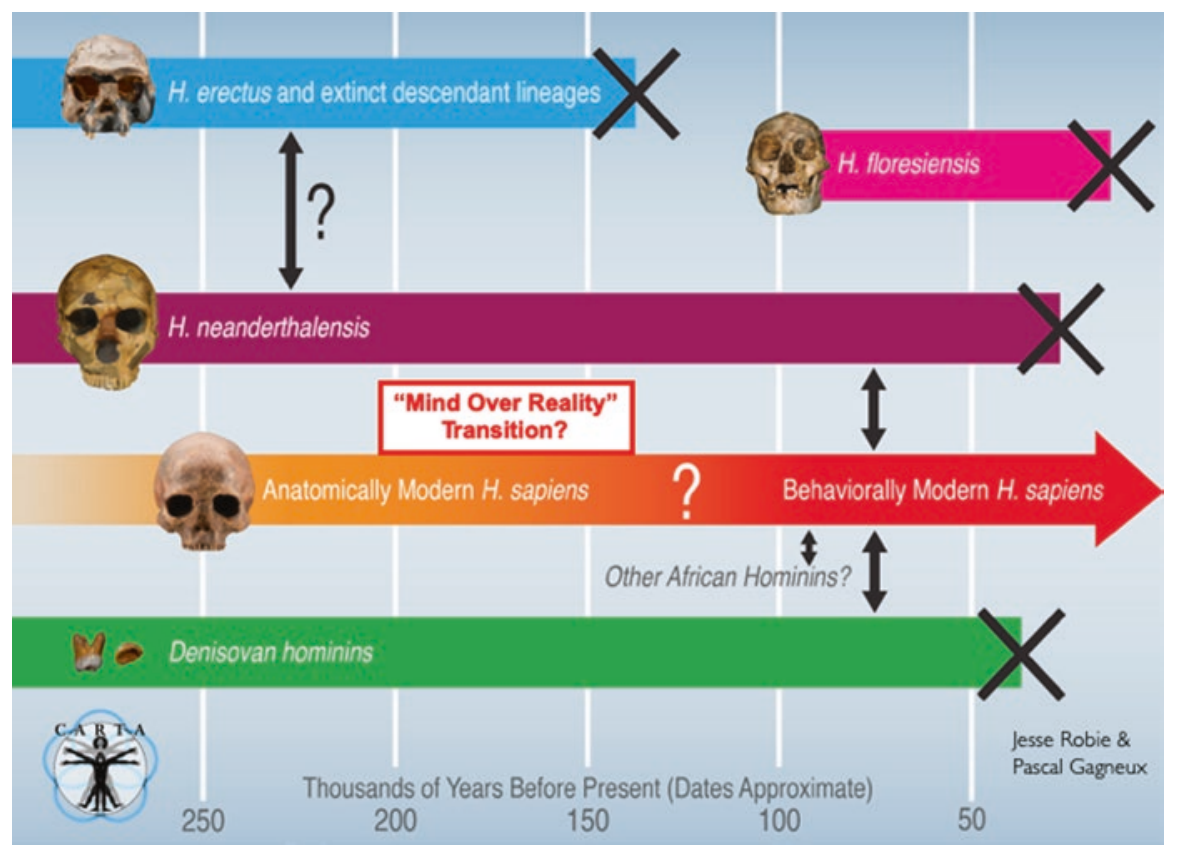

Fig. 6 Possible timing of the proposed mind over reality transition in relation to the origin of modern humans (modified from Varki A.: The Scientist 27:28-29, 2013)

Mithen, 2007; Nakahashi, 2017; Pettitt, 2010). Perhaps there they were also at the brink of the psychological evolutionary barrier, but then failed to attain the optimal combination of genes and culture to cross that Rubicon.

Does Human Psychological Ontogeny Recapitulate the Proposed Original Breaching of the Psychological Evolutionary Barrier? As shown in Fig. 7, this may also be an instance in which ontogeny does indeed recapitulate phylogeny (Clune, Pennock, Ofria, \& Lenski, 2012; Gould, 1977), in that human postnatal psychological development seems to recapitulate the proposed evolutionary transition (Moll \& Meltzoff, 2011). The proposed breaching of the psychological evolutionary barrier of mortality salience associated with the emergence of our species is perhaps being recapitulated in the death anxiety seen in young children (Barrett \& Behne, 2005; Harris, 2018; Roche, Brooten, \& Youngblut, 2019; Speece \& Brent, 1984; Vázquez-Sánchez et al., 2018), especially in nonreligious families. Parents in such families are often concerned about such anxieties, but the transition to the "invincible" adolescent more prone to take risks usually takes care of the problem over time. Also consistent with the overall theory, children with autism spectrum disorders and limited theory of mind sometimes have difficulties in understanding the concept of God (Akechi, Kikuchi, Tojo, Hakarino, \& Hasegawa, 2018; Jack, Friedman, Boyatzis, \& Taylor, 2016; Norenzayan, Gervais, \& Trzesniewski, 2012) or the deaths of others (Horowitz, Thurm, Farmer, et al., 2018). 


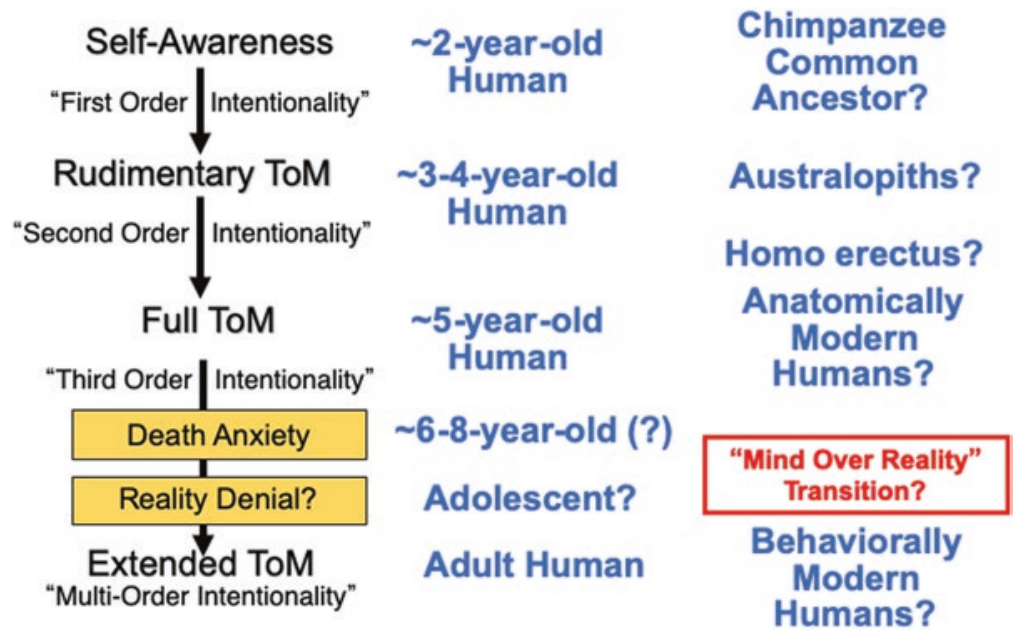

Fig. 7 Does human psychological ontogeny recapitulate our recent phylogeny?

Of course, autism spectrum disorders are not a proxy for our ancestral state, and ethical issues would constrain attempts to explore how well such individuals understand their personal mortality.

Other Examples of Potentially Supportive Evidence. As Dennett has suggested, "any theory that makes progress is bound to be initially counterintuitive" (Dennett, 1987). Any new theory is also more likely to be rejected if it originates from individuals without expertise in the relevant disciplines, and more especially if it cannot be immediately tested or falsified. But as is often done in fields like astronomy (or at the origins of the theory of evolution), one can assemble examples of potentially supportive evidence and also consider all possible "ugly facts" that might destroy the hypothesis.

The current hypothesis is consistent with "terror management theory" (Greenberg, Solomon, \& Pyszczynski, 1997; Harmon-Jones et al., 1997; Lewis, 2014; Plusnin, Pepping, \& Kashima, 2018; Pyszczynski, Greenberg, \& Solomon, 1999; Rosenblatt, Greenberg, Solomon, Pyszczynski, \& Lyon, 1989; Solomon, Greenberg, \& Pyszczynski, 1991, 2015; Vail et al., 2010) which seeks to explain defensive human thinking and behavior that arises from an awareness and fear of death, driving people to adopt worldviews that help protect their self-esteem, and making them believe that they play an important role in a meaningful world, despite the knowing of certain oblivion in the long run. Space does not allow a proper treatment of the extensive literature on Terror Management Theory (TMT) (see Pyszczynski in this volume). However, assuming that the proposed transition occurred in recent evolutionary time, human suppression of mortality salience is likely incomplete, and this partial suppression could explain the ongoing need for terror management in current-day humans. Perhaps one can suggest that MORT is to terror management theory (TMT) TMT as general relativity is to Newtonian 
physics, the former being an improved model of reality, while the latter remaining useful for everyday predictions. ${ }^{1}$

On the other hand, reality denial can be beneficial when it allows for optimism, perhaps explaining the evolutionary origins of the well-documented "optimism bias" in humans (Sharot, 2011a, 2011b; Sharot et al., 2007, 2011) which manifests itself in many human characteristics, such as the "Pollyanna hypothesis" (Iliev, Hoover, Dehghani, \& Axelrod, 2016; Schlaghecken, Blagrove, Mantantzis, Maylor, \& Watson, 2017) which addresses the apparent universal positivity bias of human language. It can also explain the human propensity for risk-taking and thrill-seeking behavior. Notably, evolutionary modeling shows that reacting in an overconfident manner can actually have fitness benefits, as long as the contested resources are sufficiently large, compared to the cost of competition (Johnson \& Fowler, 2011). On the other hand, willfully ignoring negative information can lead to disasters such as unnecessary fatalities in mountain climbers who refuse to turn back against all odds (Krakauer, 1998), ${ }^{2}$ major military losses in war (Brighton, 2004), and many other of history's greatest disasters and mistakes (Cooke, 2013).

Reality denial could also contribute to the "end-of-history illusion" (Quoidbach, Gilbert, \& Wilson, 2013), in which adults spanning a wide age range acknowledge that they have changed in many ways from how they were in the past, and yet find it hard to imagine that they will change much in the future. As the study authors put it, people seem to "regard the present as a watershed moment at which they have finally become the person they will be for the rest of their lives." This obvious denial of future reality could also help with suppression of mortality salience. Ironically, some of the same individuals are still capable of a major concern for their own posthumous legacy, despite knowing that they will not be there to be personally affected by such a legacy.

Depending on the lens through which it is studied, one aspect of religion can also be considered as strong evidence in support of MORT. Most human behaviors exist in other species on a continuum of development, as one would expect from evolution. But religion appears to be a well-established near universal only in human cultures and there are many obvious fitness advantages that have been discussed by others (Bering, 2011; Boyer, 2001, 2008; Churchland, 2011; Dennett, 2006; Maser \& Gallup, 1990; McCauley, 2011; Norenzayan \& Shariff, 2008; Schloss \& Murray, 2010; Shermer, 2012; Wade, 2009; Wilson, 2002). But most of these advantages should not require a belief in life after death. Nevertheless, almost all religions have at their core some form of such afterlife beliefs, which would serve as another mechanism to blunt the impact of mortality salience. Of course, atheists do not live

\footnotetext{
${ }^{1}$ Analogy suggested by Rob Mielcarski, whose website Un-denial (https://un-denial.com) addresses many ways in which the MORT theory is consistent with the reality of the current human condition as well as the dismal fate of our species.

2 "Unfortunately, the sort of individual who is programmed to ignore personal distress and keep pushing for the top is frequently programmed to disregard signs of grave and imminent danger as well. This forms the nub of a dilemma that every Everest climber eventually comes up against: in order to succeed you must be exceedingly driven, but if you're too driven you're likely to die." Jon Krakauer, pg. 177
} 
in constant fear of their mortality (Dawkins, 2008; Harris, 2005; Hitchens, 2009), so the underlying reality denial appears to be the primary mechanism.

Meanwhile, the dark side of mortality salience is the ability to take a decision to commit suicide (Braun, Bschor, Franklin, \& Baethge, 2016; Humphrey, 2018; Jamison, 1999; Preti, 2007; Soole, Kõlves, \& De Leo, 2015; Stoff \& Mann, 1997). This uniquely human phenomenon varies in frequency in time and space in different cultures, but also occurs at a baseline rate in all populations, driven in part by major depressive disorder (Angst, Angst, \& Stassen, 1999; Jamison, 1999), a common human psychiatric condition often characterized by "depressive realism" (Haaga \& Beck, 1995; Moore \& Fresco, 2012; Pacini, Muir, \& Epstein, 1998), a concept that suggests that mildly depressed individuals are better at perceiving certain (largely negative) aspects of reality.

If at least some aspects of depression are related to a failure of reality denial, i.e., an inability to sustain the "optimism bias," perhaps the dramatic effects of ketamine in major depressive disorder (Caddy, Amit, McCloud, et al., 2015; DeWilde, Levitch, Murrough, Mathew, \& Iosifescu, 2015; Kraus, Rabl, Vanicek, et al., 2017; Machado-Vieira, Salvadore, Diazgranados, \& Zarate, 2009; Parsaik, Singh, KhoshChashm, \& Mascarenhas, 2015) partially constitute a sudden reset into altered reality. In this regard, could the well-known human craving for mind-altering substances also be partly due to the need to escape reality? Could the same be true of the positive value of meditation methods that focus on mindfulness of the present, or the shutting out of irksome reality? Conversely, could episodic panic attacks (Bighelli, Castellazzi, Cipriani, et al., 2018; Imai, Tajika, Chen, Pompoli, \& Furukawa, 2016; Meuret, Kroll, \& Ritz, 2017) represent a sudden failure of the neural mechanisms of reality denial? The reader may detect a tendency here toward an umbrella theory, but the fact remains that all the speculative suggestions above are consistent with the MORT theory.

\section{Features of Human Sex and Gender Potentially Relevant to the Proposed Transition}

Assuming that such an evolutionary transition did occur, what might have been the contributions of sex and gender? As illustrated in the very speculative Fig. 8, human males are at greater risk of autism spectrum disorders, more prone to selective reality denial, systematizing, optimism bias, and risk-taking behavior. Conversely, human females are more prone to empathy, cooperation, theory of mind, depressive realism, and major depressive disorder. Considering these sex and gender differences (which are of course on a continuum, and affected by many cultural and genetic factors), could it be that the original evolutionary transition involved mating of males with a complex genotype manifesting as maladaptive reality denial-with females having an equally complex genotype, suffering from mortality salience due to an enhanced theory of mind? Although we cannot know for certain, could such mating have generated an unusual collection of alleles, as an explanation for the 
Fig. 8 Speculation regarding features of human sex and gender that are potentially relevant to the theory

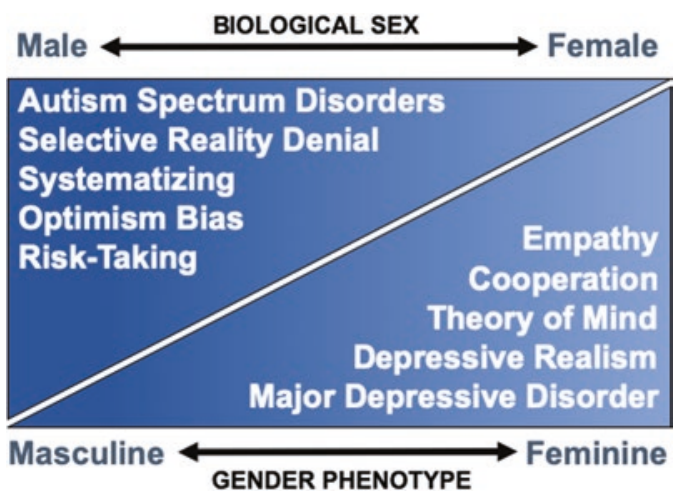

origin of humans? Assuming that generating and stabilizing the optimal combination of such alleles were was difficult, perhaps it took a very long time. Perhaps there was a prolonged interim state of recurrent cognitive instability, with ongoing dangers resulting from reality denial and/or existential angst, and possibly even high rates of suicide. Could this difficult transition explain the $>100,000$-year gap between the genetic origin of modern humans and archeological evidence suggesting our emergence in Africa and then elsewhere?

\section{Issues Arising and Future Directions}

Regardless of the sweeping speculations above, we have stated at the outset that the current theory is not falsifiable at this time. Thus, it is vital to search for "ugly facts" that might destroy the hypothesis. Although no such facts have yet emerged, there are many aspects of the earlier discussion that were oversimplified. For example, the mirror self-recognition test is not proof of self-awareness, the evidence for selfawareness in some nonhuman species is not definitive, and self-awareness in various distantly related species may not have necessarily evolved from the same neural processes. It is also true that theory of mind is not a clearly definable concept, that some other mammals and birds may have something approaching a full theory of mind, and that Neanderthals have left some evidence for an extended theory of mind, including burials and injured elderly individuals who must have been cared for (Ekshtain \& Tryon, 2019; Morin \& Laroulandie, 2012; Nakahashi, 2017; Pettitt, 2010; Staubwasser, Drăgușin, Onac, et al., 2018). Considering the archeological record, stone tool production must have required some degree of teaching, verbal communication, or at minimum active demonstration that was occurring prior to the appearance of modern humans (Asfaw, Gilbert, Beyene, et al., 2002), and the production of ochre pigment (Rosso, Pitarch Martí, \& d'Errico, 2016), and long-range transport of obsidian toolmaking materials (Blegen, Jicha, \& McBrearty, 2018) also predates evidence for modern humans. 
Meanwhile, some would suggest that the biological sex drive should have superseded fear of mortality salience or that extended theory of mind and reality denial could have coevolved gradually. If so the question remains why only in one species? The argument that a rational human can deal with mortality fears with facts and statistics is not relevant to the suggested evolutionary scenario, as the initially maladaptive mortality salience would have emerged in just a few individuals, who would likely be without any facts or statistics to help rationalize the intense fear of death.

\section{Potential Neuroanatomic Correlates of the Theory}

If this theory is correct, modern humans should have unique neural pathways that mediated the proposed evolutionary changes. Candidate brain regions include the amygdala (the brain's "danger hub" that activates natural "fight-or-flight" response to danger and death risk) (Barger, Stefanacci, Schumann, et al., 2012; Barger, Stefanacci, \& Semendeferi, 2007; Carlo, Stefanacci, Semendeferi, \& Stevens, 2010; Feinstein, Adolphs, Damasio, \& Tranel, 2011; Johansen, Cain, Ostroff, \& LeDoux, 2011; Kim, Dager, \& Lyoo, 2012; Kliemann, Dziobek, Hatri, Baudewig, \& Heekeren, 2012; Quirin, Loktyushin, Arndt, et al., 2012; Roozendaal, McEwen, \& Chattarji, 2009; Weisholtz, Root, Butler, et al., 2015); the prefrontal cortex (involved in judgments, decision-making, problem-solving, and controlling the amygdala during stressful events) (Blakemore \& Robbins, 2012; Fuster, 2008; Kuss et al., 2015; Mitchell, 2009; Tamir \& Mitchell, 2010); and the anterior cingulate cortex (involved in responding to mistakes, motivation, staying focused on a task, and managing proper emotional reactions) (Ecker, Suckling, Deoni, et al., 2012; Quirin et al., 2012; Rilling et al., 2012; Sharot et al., 2007). These also happen to be some of the regions that have undergone major anatomical changes in humans compared with our closest living evolutionary cousins (Barger et al., 2007, 2012; Rilling et al., 2012; Sakai, Mikami, Tomonaga, et al., 2011), and in which fMRI studies of optimism bias show evidence of activity (Sharot et al., 2007). All these are obviously highly oversimplified views of very complex neural structures and pathways, but they are at least consistent with the theory.

A Potentially Unifying Explanation. Overall, this "mind over reality transition" theory provides a potentially unifying explanation for the evolutionary origins of several unusual or exaggerated features of human cognition, including:

- Extended "theory of mind" (required or beneficial for many other aspects of human cognition)

- The ability for reality denial, even when aware of facts

- A strong tendency for self-deception and false beliefs

- Overarching optimism bias

- Irrational risk-taking behavior

- Recent emergence as the dominant species on the planet (perhaps making use of the above attributes) 
- Replacement of all other closely related evolutionary cousins, with limited interbreeding

The theory is also consistent with all known facts, compatible with all other related theories, and not negated by any currently known facts. On the other hand, it is not directly testable by experimental reproduction and not directly falsifiable by experimental approaches. Given also the counterintuitive nature and unusual origins of this theory, as well as the lack of expertise of the originators in many relevant disciplines, MORT is very likely to be attacked from many quarters, and resolution is unlikely during the lifetime of this author. Only the passage of time will tell if MORT is as important as plate tectonics or as completely fanciful as "phlogiston" (or something somewhere in between). Fortunately, concern for posthumous legacy is a largely meaningless exercise. ${ }^{3}$

Coda: Relevance to the Current Human Condition and the Future of Our Species. The 2007 draft of Danny Brower's incomplete manuscript that I modified and expanded into a co-authored book (Varki \& Brower, 2013) included the following prescient observations: "We are polluting the earth and changing the climate in ways that we can't predict, and likely at some point, can't easily reverse. If we're so smart, why do we continue to sow the seeds for our eventual destruction? Because we are saddled with a brain that is designed by selection to cope with the ultimate disaster (death) by denying that it will occur, and so we treat other impending disasters by denying that they will ever happen ...... Indeed, it is arguable that we are destined ultimately to destroy ourselves as a species." Although many of our follies arising from reality denial can at least theoretically be eventually reversed, there are two that definitely cannot be turned back once they occur: global nuclear holocaust and anthropogenic climate change. Although not an expert on climate, discussions with such individuals lead me to the conclusion that the human-induced climate disruption is already occurring, and that absent major changes in current human behavior and/or human intervention there is a very high probability of irreversible global catastrophic climate disruption before mid-century (Gilding, 2012; Gore, 2007, 2013; Guterl, 2012; Hansen, Sato, \& Ruedy, 2012; Mann, 2012; WallaceWells, 2019), i.e., a "climate holocaust." In other words, we are putting our children on an airplane with a very high probability of a catastrophic crash (McKibben, 2019; Rich, 2019). If this theory regarding the evolutionary origins of human reality denial is true, the first step to reversing the situation would seem to be a full awareness of our genetic tendency to reality denial by the media, and by our scientific and political leaders. Sadly, it is unlikely that rational discussion or scientific details will be sufficient to sway the average human to do what is right for the future of our species, let alone leaders who are focused on near-term political and economic goals. The only solution then may be "legitimate fear-mongering"! It is notable that it was such fear-mongering that once brought all the nations of the world together during

\footnotetext{
3 "I cannot possibly believe that a false theory would explain so many classes of facts as I think it certainly does explain.....on these grounds I drop my anchor, and believe that the difficulties will slowly disappear."-Charles Darwin, letter to Asa Gray, shortly after Origin of Species was published.
} 
the Cold War, to minimize the risk of a nuclear holocaust (Caldicott, 2017). The only other hope may be to combine fear with shame and guilt, imposed upon adult humans by adolescent school children, who can better imagine the dire future we are leaving them to face (Kjeldahl \& Hendricks, 2019). As the 15-year-old Greta Thunberg said to the elites at Davos: "I want you to feel the fear I feel every day. And act as if your house is on fire. Because it is." Of course, even if we manage to avoid catastrophic climate disruption, there are the other existential threats to our species that reality denial makes us prone to, such as widespread and indiscriminate applications of artificial intelligence (Müller, 2016) to the generation of "deep fake videos" (Stover, 2018) and other gross distortions of reality at a populationwide level. If this theory turns out to be the correct explanation for the origin of the species, it might ironically also be now sowing the seeds of our demise.

Acknowledgements The author thanks Sharon Brower, Stuart Firestein, Pascal Gagneux, Stephan Kaufhold, Rob Mielcarski, Todd Shackelford, and Virgil Zeigler-Hill for specific comments and criticisms, many members of the Center for Academic Research and Training in Anthropogeny for inspiring discussions, and the late Danny Brower for the original ideas that lead to this theory.

\section{References $^{4}$}

Akechi, H., Kikuchi, Y., Tojo, Y., Hakarino, K., \& Hasegawa, T. (2018). Mind perception and moral judgment in autism. Autism Research, 11, 1239-1244.

Anderson, J. R., \& Gallup, G. G. (2015). Mirror self-recognition: A review and critique of attempts to promote and engineer self-recognition in primates. Primates, 56, 317-326.

Anderson, J. R., Gillies, A., \& Lock, L. C. (2010). Pan thanatology. [letter]. Current Biology, 20(8), R349-R351.

Angst, J., Angst, F., \& Stassen, H. H. (1999). Suicide risk in patients with major depressive disorder. The Journal of Clinical Psychiatry, 60(Suppl 2), 57-62. discussion 75.

Apperly, I. (2010). Mindreaders: The cognitive basis of "theory of mind" (p. 232). New York: Psychology Press.

Ariely, D. (2008). Predictably irrational: The hidden forces that shape our decisions (Vol. xxii, p. 280). New York: Harper.

Asfaw, B., Gilbert, W. H., Beyene, Y., et al. (2002). Remains of Homo erectus from Bouri, Middle Awash, Ethiopia. Nature, 416, 317-320.

Barger, N., Stefanacci, L., Schumann, C. M., et al. (2012). Neuronal populations in the basolateral nuclei of the amygdala are differentially increased in humans compared with apes: A stereological study. Journal of Comparative Neurology, 520, 3035-3054.

Barger, N., Stefanacci, L., \& Semendeferi, K. (2007). A comparative volumetric analysis of the amygdaloid complex and basolateral division in the human and ape brain. American Journal of Physical Anthropology, 134, 392-403.

Baron-Cohen, S., Leslie, A. M., \& Frith, U. (1985). Does the autistic child have a "theory of mind"? Cognition, 21, 37-46.

\footnotetext{
${ }^{4}$ This work draws from a vast range of areas of human knowledge, most of which the author has limited expertise in. Thus, the citations are undoubtedly incomplete and very likely not always the best choices. The author also apologizes for the likely errors of omission and commission in the selection of the citations.
} 
Baron-Cohen, S., O’Riordan, M., Stone, V., Jones, R., \& Plaisted, K. (1999). Recognition of faux pas by normally developing children and children with Asperger syndrome or high-functioning autism. Journal of Autism and Developmental Disorders, 29, 407-418.

Barrett, H. C., \& Behne, T. (2005). Children's understanding of death as the cessation of agency: A test using sleep versus death. Cognition, 96, 93-108.

Bearzi, G., Kerem, D., Furey, N. B., Pitman, R. L., Rendell, L., \& Reeves, R. R. (2018). Whale and dolphin behavioural responses to dead conspecifics. Zoology (Jena, Germany), 128, 1-15.

Bedny, M., Pascual-Leone, A., \& Saxe, R. R. (2009). Growing up blind does not change the neural bases of Theory of Mind. Proceedings of the National Academy of Sciences, 106, 11312-11317.

Bering, J. (2011). The belief instinct: The psychology of souls, destiny, and the meaning of life (p. $\mathrm{cm})$. New York: W.W. Norton \& Company.

Bering, J. M., \& Parker, B. D. (2006). Children's attributions of intentions to an invisible agent. Developmental Psychology, 42, 253-262.

Bighelli, I., Castellazzi, M., Cipriani, A., et al. (2018). Antidepressants versus placebo for panic disorder in adults. Cochrane Database of Systematic Reviews, 4, CD010676.

Biro, D., Humle, T., Koops, K., Sousa, C., Hayashi, M., \& Matsuzawa, T. (2010). Chimpanzee mothers at Bossou, Guinea carry the mummified remains of their dead infants. Current Biology, 20, R351-R352.

Blakemore, S. J., \& Robbins, T. W. (2012). Decision-making in the adolescent brain. Nature Neuroscience, 15, 1184-1191.

Blegen, N., Jicha, B. R., \& McBrearty, S. (2018). A new tephrochronology for early diverse stone tool technologies and long-distance raw material transport in the Middle to Late Pleistocene Kapthurin Formation, East Africa. Journal of Human Evolution, 121, 75-103.

Boyer, P. (2001). Religion explained: The evolutionary origins of religious thought (Vol. vii, p. 375). New York: Basic Books.

Boyer, P. (2008). Being human: Religion: Bound to believe? Nature, 455, 1038-1039.

Braun, C., Bschor, T., Franklin, J., \& Baethge, C. (2016). Suicides and suicide attempts during long-term treatment with antidepressants: A Meta-analysis of 29 placebo-controlled studies including 6,934 patients with major depressive disorder. Psychotherapy and Psychosomatics, $85,171-179$.

Brighton, T. (2004). Hell riders: The true story of the charge of the light brigade (Vol. xxii, p. 370). New York: Henry Holt. [16] p. of plates.

Caddy, C., Amit, B. H., McCloud, T. L., et al. (2015). Ketamine and other glutamate receptor modulators for depression in adults. Cochrane Database of Systematic Reviews, CD011612. https://doi.org/10.1002/14651858.CD011611.pub2

Caldicott, H. (2017). Sleepwalking to armageddon: The threat of nuclear annihilation (Vol. xviii, p. 232). New York: The New Press.

Candland, D. K. (1995). Feral children and clever animals: Reflections on human nature (p. 432). USA: Oxford University Press.

Carlo, C. N., Stefanacci, L., Semendeferi, K., \& Stevens, C. F. (2010). Comparative analyses of the neuron numbers and volumes of the amygdaloid complex in old and new world primates. Journal of Comparative Neurology, 518, 1176-1198.

Carter, R. (2002). Exploring consciousness (Vol. 320). Berkeley: University of California Press.

Chou, H. H., Takematsu, H., Diaz, S., et al. (1998). A mutation in human CMP-sialic acid hydroxylase occurred after the Homo-Pan divergence. Proceedings of the National Academy of Sciences of the United States of America, 95, 11751-11756.

Churchland, P. S. (2011). Braintrust: What neuroscience tells us about morality. Princeton, NJ: Princeton University Press.

Clarkson, C., Jacobs, Z., Marwick, B., et al. (2017). Human occupation of northern Australia by 65,000 years ago. Nature, 547, 306-310.

Clary, D., \& Kelly, D. M. (2016). Graded mirror self-recognition by clark's nutcrackers. Scientific Reports, 6, 36459.

Clune, J., Pennock, R. T., Ofria, C., \& Lenski, R. E. (2012). Ontogeny tends to recapitulate phylogeny in digital organisms. The American Naturalist, 180, E54-E63. 
Cooke, T. (2013). Atlas of history's greatest disasters \& mistakes: The 50 most significant moments explored in words and maps. New York: Metro Books; 1 atlas (223 pages).

Corriveau, K. H., Kim, A. L., Schwalen, C. E., \& Harris, P. L. (2009). Abraham Lincoln and Harry Potter: Children's differentiation between historical and fantasy characters. Cognition, 113, 213-225.

Crockford, C., Wittig, R. M., Mundry, R., \& Zuberbuhler, K. (2012). Wild chimpanzees inform ignorant group members of danger. Current Biology, 22, 142-146.

Culotta, E. (2016). HUMAN ORIGINS. Likely hobbit ancestors lived 600,000 years earlier. Science, 352, 1260-1261.

Dale, R., \& Plotnik, J. M. (2017). Elephants know when their bodies are obstacles to success in a novel transfer task. Scientific Reports, 7, 46309.

Dawkins, R. (2008). The God delusion (p. 463). Boston: Houghton Mifflin.

Dennett, D. C. (1987). The intentional stance (Vol. xi, p. 388). Cambridge, MA: MIT Press.

Dennett, D. C. (1996). Kinds of minds: Toward an understanding of consciousness (p. 184). New York: BasicBooks/Weidenfeld and Nicolson.

Dennett, D. C. (2006). Breaking the spell: Religion as a natural phenomenon (Vol. xvi, p. 448). New York: Viking.

DeWilde, K. E., Levitch, C. F., Murrough, J. W., Mathew, S. J., \& Iosifescu, D. V. (2015). The promise of ketamine for treatment-resistant depression: Current evidence and future directions. Annals of the New York Academy of Sciences, 1345, 47-58.

Dumontheil, I., Apperly, I. A., \& Blakemore, S. J. (2010). Online usage of theory of mind continues to develop in late adolescence. Developmental Science, 13, 331-338.

Ecker, C., Suckling, J., Deoni, S. C., et al. (2012). Brain anatomy and its relationship to behavior in adults with autism spectrum disorder: A multicenter magnetic resonance imaging study. Archives of General Psychiatry, 69, 195-209.

Eddy, T. J., Gallup, G. G., \& Povinelli, D. J. (1996). Age differences in the ability of chimpanzees to distinguish mirror-images of self from video images of others. Journal of Comparative Psychology, 110, 38-44.

Ekshtain, R., \& Tryon, C. A. (2019). Lithic raw material acquisition and use by early Homo sapiens at Skhul, Israel. Journal of Human Evolution, 127, 149-170.

Emery, N. J., \& Clayton, N. S. (2009). Comparative social cognition. Annual Review of Psychology, $60,87-113$.

Enard, W., Khaitovich, P., Klose, J., et al. (2002). Intra- and interspecific variation in primate gene expression patterns. Science, 296, 340-343.

Waal, F. B. M. D. (2019). Mama's last hug: Animal emotions and what they tell us about ourselves. New York: W.W. Norton.

Feinstein, J. S., Adolphs, R., Damasio, A., \& Tranel, D. (2011). The human amygdala and the induction and experience of fear. Current Biology, 21, 34-38.

Finlayson, C., Brown, K., Blasco, R., et al. (2012). Birds of a feather: Neanderthal exploitation of raptors and corvids. PLoS One, e45927, 7.

Freeman, A. L. J., \& Spiegelhalter, D. J. (2018). Communicating health risks in science publications: Time for everyone to take responsibility. BMC Medicine, 16, 207.

Froehle, A. W., Wells, G. K., Pollom, T. R., Mabulla, A. Z. P., Lew-Levy, S., \& Crittenden, A. N. (2019). Physical activity and time budgets of Hadza forager children: Implications for selfprovisioning and the ontogeny of the sexual division of labor. American Journal of Human Biology, 31, e23209.

Fuster, J. (2008). The prefrontal cortex (4th ed.p. 424). New York: Academic Press.

Gagneux, P., Moore, J. J., \& Varki, A. (2005). The ethics of research on great apes. Nature, 437, $27-29$.

Gallup, G. G. J. (1977). Absence of self-recognition in a monkey (Macaca fascicularis) following prolonged exposure to a mirror. Developmental Psychobiology, 10, 281-284.

Galway-Witham, J., \& Stringer, C. (2018). How did Homo sapiens evolve. Science, 360, 1296-1298.

Gentner, D., \& Goldin-Meadow, S. (2003). Language in mind: Advances in the study of language and thought. A Bradford Book (p 538). MIT Press Cambridge, MA, USA 
Ghaderi, D., Springer, S. A., Ma, F., et al. (2011). Sexual selection by female immunity against paternal antigens can fix loss of function alleles. Proceedings of the National Academy of Sciences of the United States of America, 108, 17743-17748.

Gilbert, D. (2007). Stumbling on happiness (p. 336). New York: Vintage.

Gilding, P. (2012). The great disruption: Why the climate crisis will bring on the end of shopping and the birth of a new world (p. 304). London: Bloomsbury Press.

Goncalves, A., \& Biro, D. (2018). Comparative thanatology, an integrative approach: Exploring sensory/cognitive aspects of death recognition in vertebrates and invertebrates. Philosophical Transactions of the Royal Society of London. Series B, Biological Sciences, 373. https://doi. org/10.1098/rstb.2017.0263

Goncalves, A., \& Carvalho, S. (2019). Death among primates: A critical review of non-human primate interactions towards their dead and dying. Biological Reviews of the Cambridge Philosophical Society, 94(4), 1502-1529.

Gore, A. (2007). AN inconvenient truth: The crisis of global warming (p. 192). New York: Viking Juvenile.

Gore, A. (2013). The future: Six drivers of global change (p. 592). New York: Random House.

Gould, S. J. (1977). Ontogeny and phylogeny (Vol. ix, p. 501). Cambridge, MA: Belknap Press of Harvard University Press.

Greenberg, J., Solomon, S., \& Pyszczynski, T. (1997). Terror management theory of self-esteem and cultural worldviews: Empirical assessments and conceptual refinements. Advances in Experimental Social Psychology, 29, 61-139.

Guterl, F. (2012). The fate of the species: Why the human race may cause its own extinction and how we can stop it (p. 224). New York: Bloomsbury.

Haaga, D. A., \& Beck, A. T. (1995). Perspectives on depressive realism: Implications for cognitive theory of depression. Behaviour Research and Therapy, 33, 41-48.

Hajdinjak, M., Fu, Q., Hübner, A., et al. (2018). Reconstructing the genetic history of late Neanderthals. Nature, 555, 652-656.

Hansen, J., Sato, M., \& Ruedy, R. (2012). Perception of climate change. Proceedings of the National Academy of Sciences of the United States of America, 109, E2415-E2423.

Harmon-Jones, E. (2019). Cognitive dissonance: Reexamining a pivotal theory in psychology (p. $\mathrm{cm})$. Washington, DC: American Psychological Association.

Harmon-Jones, E., Simon, L., Greenberg, J., Pyszczynski, T., Solomon, S., \& McGregor, H. (1997). Terror management theory and self-esteem: Evidence that increased self-esteem reduces mortality salience effects. Journal of Personality and Social Psychology, 72, 24-36.

Harris, P. L. (2018). Children's understanding of death: From biology to religion. Philosophical Transactions of the Royal Society of London. Series B, Biological Sciences, 373. https://doi. org/10.1098/rstb.2017.0266

Harris, S. (2005). The end of faith: Religion, terror, and the future of reason (p. 352). New York: W. W. Norton.

Hayakawa, T., Angata, T., Lewis, A. L., Mikkelsen, T. S., Varki, N. M., \& Varki, A. (2005). A human-specific gene in microglia. Science, 309, 1693.

Hedlund, M., Padler-Karavani, V., Varki, N. M., \& Varki, A. (2008). Evidence for a humanspecific mechanism for diet and antibody-mediated inflammation in carcinoma progression. Proceedings of the National Academy of Sciences of the United States of America, 105, 18936-18941.

Heyes, C. M., \& Frith, C. D. (2014). The cultural evolution of mind reading. Science, 344, 1243091.

Hitchens, C. (2009). God is not great: How religion poisons everything (p. 336). New York: Twelve.

Hodges, S. D., Denning, K. R., \& Lieber, S. (2018). Perspective taking: Motivation and impediment to shared reality. Current Opinion in Psychology, 23, 104-108.

Hofmann, S. G., Doan, S. N., Sprung, M., et al. (2016). Training children's theory-of-mind: A meta-analysis of controlled studies. Cognition, 150, 200-212.

Horowitz, L. M., Thurm, A., Farmer, C., et al. (2018). Talking about death or suicide: Prevalence and clinical correlates in youth with autism spectrum disorder in the psychiatric inpatient setting. Journal of Autism and Developmental Disorders, 48, 3702-3710. 
Hrdy, S. B. (2009). Mothers and others: The evolutionary origins of mutual understanding (p. 422). Cambridge, MA: Belknap Press of Harvard University Press.

Hublin, J. J., Ben-Ncer, A., Bailey, S. E., et al. (2017). New fossils from Jebel Irhoud, Morocco and the pan-African origin of Homo sapiens. Nature, 546, 289-292.

Humphrey, N. (2018). The lure of death: Suicide and human evolution. Philosophical Transactions of the Royal Society of London. Series B, Biological Sciences, 373. https://doi.org/10.1098/ rstb.2017.0269

Huttunen, A. W., Adams, G. K., \& Platt, M. L. (2017). Can self-awareness be taught? Monkeys pass the mirror test-again. Proceedings of the National Academy of Sciences of the United States of America, 114, 3281-3283.

Iliev, R., Hoover, J., Dehghani, M., \& Axelrod, R. (2016). Linguistic positivity in historical texts reflects dynamic environmental and psychological factors. Proceedings of the National Academy of Sciences of the United States of America, 113, E7871-E7879.

Imai, H., Tajika, A., Chen, P., Pompoli, A., \& Furukawa, T. A. (2016). Psychological therapies versus pharmacological interventions for panic disorder with or without agoraphobia in adults. Cochrane Database of Systematic Reviews, 10, CD011170.

Jack, A. I., Friedman, J. P., Boyatzis, R. E., \& Taylor, S. N. (2016). Why do you believe in god? relationships between religious belief, analytic thinking, mentalizing and moral concern. PLoS One, 11, e0149989.

Jacobs, G. S., Hudjashov, G., Saag, L., et al. (2019). Multiple deeply divergent denisovan ancestries in papuans. Cell, 177(4), 1010-1021.e32.

Jamison, K. R. (1999). Night falls fast understanding suicide (Vol. x, p. 432). New York: Knopf.

Johansen, J. P., Cain, C. K., Ostroff, L. E., \& LeDoux, J. E. (2011). Molecular mechanisms of fear learning and memory. Cell, 147, 509-524.

Johnson, D. D., \& Fowler, J. H. (2011). The evolution of overconfidence. Nature, 477, 317-320.

Kappeler, P. M., \& Silk, J. B. (2010). Mind the gap: Tracing the origins of human universals. (Vol. xix, p. 503). Heidelberg: Springer.

Kim, J. E., Dager, S. R., \& Lyoo, I. K. (2012). The role of the amygdala in the pathophysiology of panic disorder: Evidence from neuroimaging studies. Biology of Mood and Anxiety Disorders, $2,20$.

Kitchen, A., Denton, D., \& Brent, L. (1996). Self-recognition and abstraction abilities in the common chimpanzee studied with distorting mirrors. Proceedings of the National Academy of Sciences of the United States of America, 93, 7405-7408.

Kjeldahl, E. M., \& Hendricks, V. F. (2019). Response by the authors. EMBO Reports, 20, e47764.

Kliemann, D., Dziobek, I., Hatri, A., Baudewig, J., \& Heekeren, H. R. (2012). The role of the amygdala in atypical gaze on emotional faces in autism spectrum disorders. The Journal of Neuroscience, 32, 9469-9476.

Konner, M. (2010). The evolution of childhood: Relationships, emotion, mind (Vol. xv, p. 943). Cambridge, MA: Belknap Press of Harvard University Press.

Krakauer, J. (1998). Into thin air: A personal account of the Mount Everest disaster (Vol. xxii, p. 407). New York: Villard.

Kraus, C., Rabl, U., Vanicek, T., et al. (2017). Administration of ketamine for unipolar and bipolar depression. International Journal of Psychiatry in Clinical Practice, 21, 2-12.

Krupenye, C., Kano, F., Hirata, S., Call, J., \& Tomasello, M. (2016). Great apes anticipate that other individuals will act according to false beliefs. Science, 354, 110-114.

Kuss, K., Falk, A., Trautner, P., Montag, C., Weber, B., \& Fliessbach, K. (2015). Neuronal correlates of social decision making are influenced by social value orientation-an fMRI study. Frontiers in Behavioral Neuroscience, 9, 40.

Langdon, J. H. (1997). Umbrella hypotheses and parsimony in human evolution: A critique of the Aquatic Ape Hypothesis. Journal of Human Evolution, 33, 479-494.

Lewis, A. M. (2014). Terror management theory applied clinically: Implications for existentialintegrative psychotherapy. Death Studies, 38, 412-417.

Luu, B., Rosnay, M., \& Harris, P. L. (2013). Five-year-olds are willing, but 4-year-olds refuse, to trust informants who offer new and unfamiliar labels for parts of the body. Journal of Experimental Child Psychology, 116, 234-246. 
Machado-Vieira, R., Salvadore, G., Diazgranados, N., \& Zarate, C. A. J. (2009). Ketamine and the next generation of antidepressants with a rapid onset of action. Pharmacology \& Therapeutics, $123,143-150$.

Mann, M. E. (2012). The Hockey stick and the climate wars: Dispatches from the front lines (Vol. 384). New York: Columbia University Press.

Marzluff, J., \& Angell, T. (2012). Gifts of the crow: How perception, emotion, and thought allow smart birds to behave like humans (p. 304). New York: Free Press.

Maser, J. D., \& Gallup, G. G. (1990). Theism as a by-product of natural selection. The Journal of Religion., 70, 515-532.

McCauley, R. N. (2011). Why religion is natural and science is not (Vol. xv, p. 335). New York: Oxford University Press.

McConkey, E. H., \& Varki, A. (2000). A primate genome project deserves high priority. [letter]. Science, 289(5483), 1295-1296.

McConkey, E. H., \& Varki, A. (2005). Genomics. Thoughts on the future of great ape research. Science, 309, 1499-1501.

McKibben, B. (2019). Falter: Has the human game begun to play itself out (p. cm). New York: Henry Holt and Company.

Meltzoff, A. N. (1999). Origins of theory of mind, cognition and communication. Journal of Communication Disorders, 32, 251-269.

Meuret, A. E., Kroll, J., \& Ritz, T. (2017). Panic disorder comorbidity with medical conditions and treatment implications. Annual Review of Clinical Psychology, 13, 209-240.

Meyer, M., Kircher, M., Gansauge, M. T., et al. (2012). A high-coverage genome sequence from an archaic Denisovan individual. Science, 338, 222-226.

Mitchell, J. P. (2009). Inferences about mental states. Philosophical Transactions of the Royal Society of London. Series B, Biological Sciences, 364, 1309-1316.

Mithen, S. (2007). The singing neanderthals: The origins of music, language, mind, and body (Vol. 384). Cambridge, MA: Harvard University Press.

Moll, H., \& Meltzoff, A. N. (2011). How does it look? Level 2 perspective-taking at 36 months of age. Child Development, 82, 661-673.

Moll, H., \& Tomasello, M. (2012). Three-year-olds understand appearance and reality - just not about the same object at the same time. Developmental Psychology, 48, 1124-1132.

Moore, M. T., \& Fresco, D. M. (2012). Depressive realism: A meta-analytic review. Clinical Psychology Review, 32, 496-509.

Morin, E., \& Laroulandie, V. (2012). Presumed symbolic use of diurnal raptors by Neanderthals. PLoS One, 7, e32856.

Morrison, R., \& Reiss, D. (2018). Precocious development of self-awareness in dolphins. PLoS One, 13, e0189813.

Müller, V. C. (2016). Risks of artificial intelligence (Vol. x, p. 291). Boca Raton, FL: CRC Press.

Murphy, S. C., von Hippel, W., Dubbs, S. L., et al. (2015). The role of overconfidence in romantic desirability and competition. Personality and Social Psychology Bulletin, 41, 1036-1052.

Nakahashi, W. (2017). The effect of trauma on Neanderthal culture: A mathematical analysis. Homo, 68, 83-100.

Nielsen, R., Akey, J. M., Jakobsson, M., Pritchard, J. K., Tishkoff, S., \& Willerslev, E. (2017). Tracing the peopling of the world through genomics. Nature, 541, 302-310.

Norenzayan, A., Gervais, W. M., \& Trzesniewski, K. H. (2012). Mentalizing deficits constrain belief in a personal God. PLoS One, 7, e36880.

Norenzayan, A., \& Shariff, A. F. (2008). The origin and evolution of religious prosociality. Science, $322,58-62$.

O’Bleness, M., Searles, V. B., Varki, A., Gagneux, P., \& Sikela, J. M. (2012). Evolution of genetic and genomic features unique to the human lineage. Nature Reviews Genetics, 13, 853-866.

Olson, M. V., \& Varki, A. (2003). Sequencing the chimpanzee genome: Insights into human evolution and disease. Nature Reviews Genetics, 4, 20-28.

Olson, M. V., \& Varki, A. (2004). Genomics. The chimpanzee genome - a bittersweet celebration. Science, 305, 191-192. 
Pacini, R., Muir, F., \& Epstein, S. (1998). Depressive realism from the perspective of cognitiveexperiential self-theory. Journal of Personality and Social Psychology, 74, 1056-1068.

Parker, S. T., Mitchell, R. W., \& Boccia, M. (1994). Self-awareness in animals and humans: Developmental perspectives (Vol. xviii, p. 442). Cambridge, England: Cambridge University Press.

Parsaik, A. K., Singh, B., Khosh-Chashm, D., \& Mascarenhas, S. S. (2015). Efficacy of ketamine in bipolar depression: Systematic review and meta-analysis. Journal of Psychiatric Practice, $21,427-435$.

Patel, G. H., Sestieri, C., \& Corbetta, M. (2019). The evolution of the temporoparietal junction and posterior superior temporal sulcus. Cortex. https://doi.org/10.1016/j.cortex.2019.01.026

Petr, M., Pääbo, S., Kelso, J., \& Vernot, B. (2019). Limits of long-term selection against Neanderthal introgression. Proceedings of the National Academy of Sciences of the United States of America, 116, 1639-1644.

Pettitt, P. (2010). The palaeolithic origins of human burial (p. 320). Abingdon: Routledge.

Piazza, J., Bering, J. M., \& Ingram, G. (2011). "Princess Alice is watching you": Children's belief in an invisible person inhibits cheating. Journal of Experimental Child Psychology, 109, 311-320.

Plotnik, J. M., de Waal, F. B., \& Reiss, D. (2006). Self-recognition in an Asian elephant. Proceedings of the National Academy of Sciences of the United States of America, 103, 17053-17057.

Plusnin, N., Pepping, C. A., \& Kashima, E. S. (2018). The role of close relationships in terror management: A systematic review and research agenda. Personality and Social Psychology Review, 22, 307-346.

Porter, A., Eckardt, W., Vecellio, V., et al. (2019). Behavioral responses around conspecific corpses in adult eastern gorillas (Gorilla beringei spp.). PeerJ, e6655, 7.

Povinelli, D. J., Eddy, T. J., Hobson, R. P., \& Tomasello, M. (1996). What young chimpanzees know about seeing (Vol. vi, p. 191). Chicago, IL: University of Chicago Press.

Premack, D., \& Woodruff, G. (1978). Does the chimpanzee have a theory of mind? The Behavioral and Brain Sciences, 4, 515-526.

Preti, A. (2007). Suicide among animals: A review of evidence. Psychological Reports, 101, 831-848.

Prior, H., Schwarz, A., \& Güntürkün, O. (2008). Mirror-induced behavior in the magpie (Pica pica): Evidence of self-recognition. PLoS Biology, 6, e202.

Prufer, K., de Filippo, C., Grote, S., et al. (2017). A high-coverage Neandertal genome from Vindija Cave in Croatia. Science, 358, 655-658.

Prufer, K., Racimo, F., Patterson, N., et al. (2014). The complete genome sequence of a Neanderthal from the Altai Mountains. Nature, 505, 43-49.

Pyszczynski, T., Greenberg, J., \& Solomon, S. (1999). A dual-process model of defense against conscious and unconscious death-related thoughts: An extension of terror management theory. Psychological Review, 106, 835-845.

Quirin, M., Loktyushin, A., Arndt, J., et al. (2012). Existential neuroscience: A functional magnetic resonance imaging investigation of neural responses to reminders of one's mortality. Social Cognitive and Affective Neuroscience, 7, 193-198.

Quoidbach, J., Gilbert, D. T., \& Wilson, T. D. (2013). The end of history illusion. Science, 339, 96-98.

Rajala, A. Z., Reininger, K. R., Lancaster, K. M., \& Populin, L. C. (2010). Rhesus monkeys (Macaca mulatta) do recognize themselves in the mirror: Implications for the evolution of selfrecognition. PLoS One, 5. https://doi.org/10.1371/journal.pone.0012865

Ramachandran, V. S. (1996). The evolutionary biology of self-deception, laughter, dreaming and depression: Some clues from anosognosia. Medical Hypotheses, 47, 347-362.

Reich, D., Green, R. E., Kircher, M., et al. (2010). Genetic history of an archaic hominin group from Denisova Cave in Siberia. Nature, 468, 1053-1060.

Reiss, D. (2011). The dolphin in the mirror: Exploring dolphin minds and saving dolphin lives (p. 276). Boston: Houghton Mifflin Harcourt. [8] p. of plates.

Reiss, D., \& Marino, L. (2001). Mirror self-recognition in the bottlenose dolphin: A case of cognitive convergence. Proceedings of the National Academy of Sciences of the United States of America, 98, 5937-5942. 
Rich, N. (2019). Losing Earth: A recent history (p. cm). New York: MCD/Farrar, Straus and Giroux.

Rilling, J. K., Scholz, J., Preuss, T. M., Glasser, M. F., Errangi, B. K., \& Behrens, T. E. (2012). Differences between chimpanzees and bonobos in neural systems supporting social cognition. Social Cognitive and Affective Neuroscience, 7, 369-379.

Roche, R. M., Brooten, D., \& Youngblut, J. M. (2019). Children's fears 2-13 months after sibling NICU/PICU/emergency department death. Journal of the American Association of Nurse Practitioners. https://doi.org/10.1097/JXX.0000000000000193

Ronfard, S., Bartz, D. T., Cheng, L., Chen, X., \& Harris, P. L. (2018). Children's developing ideas about knowledge and its acquisition. Advances in Child Development and Behavior, 54, 123-151.

Ronfard, S., Chen, E. E., \& Harris, P. L. (2018). The emergence of the empirical stance: Children's testing of counterintuitive claims. Developmental Psychology, 54, 482-493.

Roozendaal, B., McEwen, B. S., \& Chattarji, S. (2009). Stress, memory and the amygdala. Nature Reviews. Neuroscience, 10, 423-433.

Rosenblatt, A., Greenberg, J., Solomon, S., Pyszczynski, T., \& Lyon, D. (1989). Evidence for terror management theory: I. The effects of mortality salience on reactions to those who violate or uphold cultural values. Journal of Personality and Social Psychology, 57, 681-690.

Ross, J., Yilmaz, M., Dale, R., Cassidy, R., Yildirim, I., \& Suzanne, Z. M. (2017). Cultural differences in self-recognition: The early development of autonomous and related selves. Developmental Science, 20. https://doi.org/10.1111/desc.12387

Rosso, D. E., Pitarch Martí, A., \& d'Errico, F. (2016). Middle stone age ochre processing and behavioural complexity in the Horn of Africa: Evidence from Porc-Epic Cave, Dire Dawa, Ethiopia. PLoS One., 11, e0164793.

Safina, C. (2015). Beyond words: What animals think and feel (Vol. xiii, p. 461). New York: Henry Holt and Company. 16 unnumbered pages of plates.

Safina, C. (2019). Beyond words: What elephants and whales think and feel (p. cm). New York, NY: Roaring Brook Press.

Sakai, T., Mikami, A., Tomonaga, M., et al. (2011). Differential prefrontal white matter development in chimpanzees and humans. Current Biology, 21, 1397-1402.

Samson, D. (2009). Reading other people's mind: Insights from neuropsychology. Journal of Neuropsychology, 3, 3-16.

Schaafsma, S. M., Pfaff, D. W., Spunt, R. P., \& Adolphs, R. (2015). Deconstructing and reconstructing theory of mind. Trends in Cognitive Sciences, 19, 65-72.

Scheinfeldt, L. B., Soi, S., Lambert, C., et al. (2019). Genomic evidence for shared common ancestry of East African hunting-gathering populations and insights into local adaptation. Proceedings of the National Academy of Sciences of the United States of America. https://doi. org/10.1073/pnas.1817678116

Schlaghecken, F., Blagrove, E., Mantantzis, K., Maylor, E. A., \& Watson, D. G. (2017). Look on the bright side: Positivity bias modulates interference effects in the Simon task. Journal of Experimental Psychology. General, 146, 763-770.

Schloss, J., \& Murray, M. J. (2010). The believing primate: Scientific, philosophical, and theological reflections on the origin of religion (Vol. xii, p. 365). Oxford, New York: Oxford University Press.

Schumaker, J. F. (1995). The corruption of reality: A unified theory of religion, hypnosis, and psychopathology (p. 289). Amherst, NY: Prometheus Books.

Sharot, T. (2011a). The optimism bias. Current Biology, 21, R941-R945.

Sharot, T. (2011b). The optimism bias: A tour of the irrationally positive brain. New York, NY: Pantheon.

Sharot, T., Korn, C. W., \& Dolan, R. J. (2011). How unrealistic optimism is maintained in the face of reality. Nature Neuroscience, 14, 1475-1479.

Sharot, T., Riccardi, A. M., Raio, C. M., \& Phelps, E. A. (2007). Neural mechanisms mediating optimism bias. Nature, 450, 102-105. 
Shermer, M. (2012). The believing brain: From Ghosts and gods to politics and conspiracies how we construct beliefs and reinforce them as truths (p. 400). New York: St. Martin's Griffin.

Solomon, S., Greenberg, J., \& Pyszczynski, T. (1991). A terror management theory of social behavior: The psychological functions of self-esteem and cultural worldviews. Advances in Experimental Social Psychology, 24, 93-159.

Solomon, S., Greenberg, J., \& Pyszczynski, T. A. (2015). The worm at the core: On the role of death in life. xi, 274 pages. Penguin Books, Random House, New York

Soole, R., Kõlves, K., \& De Leo, D. (2015). Suicide in Children: A Systematic Review. Archives of Suicide Research, 19, 285-304.

Specter, M. (2009). Denialism: How irrational thinking hinders scientific progress, harms the planet, and threatens our lives (p. 304). London: Penguin Press HC.

Speece, M. W., \& Brent, S. B. (1984). Children's understanding of death: A review of three components of a death concept. Child Development, 55, 1671-1686.

Spiegelhalter, D. (2012). Using speed of ageing and "microlives" to communicate the effects of lifetime habits and environment. BMJ, 345, e8223.

Staubwasser, M., Drăgușin, V., Onac, B. P., et al. (2018). Impact of climate change on the transition of Neanderthals to modern humans in Europe. Proceedings of the National Academy of Sciences of the United States of America, 115, 9116-9121.

Stewart, F. A., Piel, A. K., \& O'Malley, R. C. (2012). Responses of chimpanzees to a recently dead community member at Gombe National Park. Tanzania. American Journal of Primatol, 74, 1-7.

Stoff, D. M., \& Mann, J. (1997). Suicide research. Annals of the New York Academy of Sciences, $836,1-11$.

Stover, D. (2018). Garlin Gilchrist: Fighting fake news and the information apocalypse. The Bulletin of the Atomic Scientists, 74, 283-288.

Stringer, C. (2012). Lone survivors: How we came to be the only humans on earth (p. cm). New York: Henry Holt and Company.

Suddendorf, T., \& Butler, D. L. (2013). The nature of visual self-recognition. Trends in Cognitive Sciences, 17, 121-127.

Tamir, D. I., \& Mitchell, J. P. (2010). Neural correlates of anchoring-and-adjustment during mentalizing. Proceedings of the National Academy of Sciences of the United States of America, 107, 10827-10832.

Tattersall I. Masters of the planet: The search for our human origins (Macsci). Palgrave Macmillan; Basingstoke 2012:288.

Toda, K., \& Platt, M. L. (2015). Animal cognition: Monkeys pass the mirror test. Current Biology, 25, R64-R66.

Tomasello, M. (2018). How children come to understand false beliefs: A shared intentionality account. Proceedings of the National Academy of Sciences of the United States of America, $115,8491-8498$.

Trivers, R. (2000). The elements of a scientific theory of self-deception. Annals of the New York Academy of Sciences, 907, 114-131.

Trivers, R. (2011). The folly of fools: The logic of deceit and self-deception in human life (p. cm). New York, NY: Basic Books.

Vail, K. E., Rothschild, Z. K., Weise, D. R., Solomon, S., Pyszczynski, T., \& Greenberg, J. (2010). A terror management analysis of the psychological functions of religion. Personality and Social Psychology Review, 14, 84-94.

Varki, A. (2000). A chimpanzee genome project is a biomedical imperative. Genome Research, $10,1065-1070$.

Varki, A. (2007). The uncertain future of research chimpanzees. Science, 315, 1493-1494.

Varki, A. (2009). Human uniqueness and the denial of death. Nature, 460, 684.

Varki, A. (2010). Colloquium paper: Uniquely human evolution of sialic acid genetics and biology. Proceedings of the National Academy of Sciences of the United States of America, 107(Suppl 2), 8939-8946. 
Varki, A. (2016). Why are there no persisting hybrids of humans with Denisovans, Neanderthals, or anyone else[letter]. Proceedings of the National Academy of Sciences of the United States of America, 113(17), E2354.

Varki, A., \& Brower, D. L. (2013). Denial: Self-deception, false beliefs, and the origins of the human mind (Vol. 375). New York: Twelve.

Varki, A., Geschwind, D. H., \& Eichler, E. E. (2008). Explaining human uniqueness: Genome interactions with environment, behaviour and culture. Nature Reviews. Genetics, 9, 749-763.

Varki, N. M., Strobert, E., Dick, E. J. J., Benirschke, K., \& Varki, A. (2011). Biomedical differences between human and nonhuman hominids: Potential roles for uniquely human aspects of sialic acid biology. Annual Review of Pathology, 6, 365-393.

Vázquez-Sánchez, J. M., Fernández-Alcántara, M., García-Caro, M. P., Cabañero-Martínez, M. J., Martí-García, C., \& Montoya-Juárez, R. (2018). The concept of death in children aged from 9 to 11 years: Evidences through inductive and deductive analysis of drawings. Death Study, 1-11. https://doi.org/10.1080/07481187.2018.1480545

Vogeley, K. (2017). Two social brains: Neural mechanisms of intersubjectivity. Philosophical Transactions of the Royal Society of London. Series B, Biological Sciences, 372. https://doi. org/10.1098/rstb.2016.0245

Wade, N. (2009). The faith instinct: How religion evolved and why it endures (p. 320). The: Penguin Press HC.

Wallace-Wells, D. (2019). The uninhabitable earth: Life after warming (p. 310). New York: Tim Duggan Books.

Wang, X., Mitra, N., Secundino, I., et al. (2012). Specific inactivation of two immunomodulatory SIGLEC genes during human evolution. Proceedings of the National Academy of Sciences of the United States of America, 109, 9935-9940.

Weinstein, N. D. (1980). Unrealistic optimism about future life events. Journal of Personality and Social Psychology, 39, 806.

Weisholtz, D. S., Root, J. C., Butler, T., et al. (2015). Beyond the amygdala: Linguistic threat modulates peri-sylvian semantic access cortices. Brain and Language, 151, 12-22.

Wellman, H. M., \& Brandone, A. C. (2009). Early intention understandings that are common to primates predict children's later theory of mind. Current Opinion in Neurobiology, 19, 57-62.

Wilson, D. S. (2002). Darwin's cathedral: Evolution, religion, and the nature of society (Vol. v, p. 268). Chicago: University of Chicago Press.

Wood, B., \& Boyle E, K. (2016). Hominin taxic diversity: Fact or fantasy. American Journal of Physical Anthropology, 159, S37-S78.

Wood, B. (2017). Evolution: Origin(s) of modern humans. Current Biology, 27, R767-R769.

Young, L., Dodell-Feder, D., \& Saxe, R. (2010). What gets the attention of the temporo-parietal junction? An fMRI investigation of attention and theory of mind. Neuropsychologia, 48, $2658-2664$.

Open Access This chapter is licensed under the terms of the Creative Commons Attribution 4.0 International License (http://creativecommons.org/licenses/by/4.0/), which permits use, sharing, adaptation, distribution and reproduction in any medium or format, as long as you give appropriate credit to the original author(s) and the source, provide a link to the Creative Commons license and indicate if changes were made.

The images or other third party material in this chapter are included in the chapter's Creative Commons license, unless indicated otherwise in a credit line to the material. If material is not included in the chapter's Creative Commons license and your intended use is not permitted by statutory regulation or exceeds the permitted use, you will need to obtain permission directly from the copyright holder.

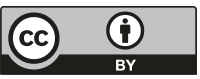

